\title{
Ssciendo
}

Ethics \& Bioethics (in Central Europe), 2019, 9 (3-4), 190-196

DOI:10.2478/ebce-2019-0013

\section{A bitter diagnostic of the ultra-liberal human: Michel Houellebecq on some ethical issues}

\author{
Zuzana Malinovská1 ${ }^{\text {\& Ján Živčák }}{ }^{2}$
}

\begin{abstract}
The paper examines the ethical dimensions of Michel Houellebecq's works of fiction. On the basis of keen diagnostics of contemporary Western culture, this world-renowned French writer predicts the destructive social consequences of ultra-liberalism and enters into an argument with transhumanist theories. His writings, depicting the misery of contemporary man and imagining a new human species enhanced by technologies, show that neither the so-called neo-humans nor the "last man" of liberal democracies can reach happiness. The latter can only be achieved if humanist values, shared by previous generations and promoted by the great $19^{\text {th }}$-century authors (Balzac, Flaubert), are reinvented.
\end{abstract}

Keywords: contemporary French literature, ultra-liberalism, humanism, transhumanism, end of man

\section{Introduction}

Since the time of Aristotle, the axiom of ontological inseparability and mutual compatibility of aesthetics and ethics within a literary work has been widely accepted by literary theorists. Even the (apparent) absence of ethics espoused by some adherents of extreme formalist experiments around the middle and in the second half of the $20^{\text {th }}$ century (e.g. the 'Tel Quel' group) presupposes an ethical positioning. In France, forms of literary expression which accord high priority to ethical/moral questioning have a significant tradition. The so-called "ethical generation", writing mainly in the 1930s (Antoine de Saint-Exupéry, Georges Bernanos, André Malraux, etc.), is clear evidence of this. At present, the French author whose ethical as well as aesthetic positions generate probably the most controversy is Michel Houellebecq (Clément \& Wesemael, 2007). Born in 1956, he has gained worldwide recognition and has been studied by numerous scholars (e.g. Murielle Lucie Clément, Sabine van Wesemael, Raphaël Baroni, Michel David, Éric Naulleau, Dominique Noguez, Bruno Viard, etc.). In his seven novels published so far, he shows a systematic interest in a number of highly topical and divisive issues such as religious fanaticism, separation of sex and love/passion, genetic manipulation, social exclusion of the old and physically unattractive, etc. The present paper aims to inspect and review the ethical scope of Houellebecq's thought, with special emphasis on his views on transhumanism and the social consequences of Western ultra-liberalism.

Two questions mark the starting point of our reflection. Both draw on the story and the assertions of Daniel 1. This protagonist of Houellebecq's 2005 novel La Possibilité d'une île [The Possibility of an island] is a jester (a profession that may refer to the policies of liberal democracies which are nothing more than big shows disguising big business, see Harari, 2016). ${ }^{3}$ He earns his living in provocative and politically incorrect shows, one of which is entitled "We prefer Palestinian sex workers" (On préfère les partouzeuses palestiniennes, see Houellebecq, 2005, pp. 47, 49, 160 ff.).

\footnotetext{
${ }^{1}$ University of Prešov, Institute of Romance Studies, Prešov (Slovakia); zuzana.malinovska@unipo.sk

${ }^{2}$ University of Prešov, Institute of Romance Studies, Prešov (Slovakia); janzivcak@gmail.com

3 See also Houellebecq, 2001, p. 319, where Michel, the protagonist of Plateforme [Platform], another of Houellebecq's novel, considers elections as "excellent TV shows" (d'excellents shows télévisés). Since the paper draws on the original versions of Houellebecq's texts, all quotations are given in our own translation with original French in footnotes and in italics. For information on existing English translations of the author's novels, please consult the final list of references.
} 
(1) Daniel 1 presents himself as a "bitter humanist" (humaniste grinçant, Houellebecq, 2005, p. 22). Can the same attribute be used to characterize the ethical positions of Daniel 1's "creator"? Certainly, Michel Houellebecq, known for his provocations, likes to scramble the lines, ${ }^{4}$ but the outlined parallel, if legitimate, might shed new light on the interweaving of ethics and aesthetics in his works.

(2) Daniel 1 is not the only narrator of his life story. He is assisted by his clones Daniel 24 and Daniel 25. Can the author's narrative strategy be interpreted as an aesthetic foreshadowing of the long-announced end of man, discussed by philosophers (see, for example, Fukuyama, 1992; Foucault, 1970)? And can an ethically acceptable vision of the future, as seen by the author, reside in the arrival of the so-called neo-humans, post-biological creatures genetically derived from their human predecessors?

The most comprehensive answer to these questions lies in the moral and sociological profile of contemporary ultra-liberal man whose image is transposed into Houellebecq's fictional characters. But before moving on to the analyses, it should be pointed out that we adhere to the part of academic community that considers Michel Houellebecq to be a worthy writer (Viard, 2013). Although some scholars give him unflattering reviews (Baroni \& Estier, 2016; Manilève, 2015), he is, in our opinion, an excellent observer; a kind of Balzac of the $21^{\text {st }}$ century, ${ }^{5}$ who gives a precise diagnosis of the man of liberal democracies. It is not by chance that his writings keep arousing the interest of philosophers, ethicists, sociologists, politicians and linguists.

\section{A determinist vision of the last man}

Since the publication of the author's first novel Extension du domaine de la lutte [Whatever] in 1994, Houellebecqian heroes demonstrate pretty much the same traits. The protagonistsnarrators - Michel in Les Particules élémentaires [The elementary particles] and Plateforme, Daniel 1 in La Possibilité d'une île, Jed in La Carte et le territoire [The map and the territory] or François in Soumission [Submission] - can all be seen as variants of a representative member ${ }^{6}$ of contemporary Western society: a young single man, solitary and depressed, fed by mass culture and leading a flat life filled with futile distractions. ${ }^{7}$ Thanks to a well-paid job (analyst programmer, official, artist, scholar etc.) he is quite immune to material and financial problems in a brutal world driven by money. ${ }^{8}$ He enjoys the benefits of permissive society, but suffers from emotional misery and proves to be unfit for friendship and love. To bear this existence, "that painful and definitive disaster" (Houellebecq, 1994, p. 13), ${ }^{9}$ he resorts to excessive consumption and sexual adventures with no real desire or pleasure. Often patterned as a selfprojection of the writer, he adopts the role of an impassive observer ${ }^{10}$ astonished by the spectacle of the world. Just as his "creator" - whom we might call the entomologist of the last man (an allusion to Zola and Nietzsche) - this (anti-)hero watches his fellows "walk on each other like lobsters in a jar" (Houellebecq, 1994, p. 16). ${ }^{11}$

\footnotetext{
${ }^{4}$ François, the protagonist-narrator of Soumission and a possible self-projection of the author, declares that "the mere mention of the word 'humanism' made [him] feel slightly like vomiting" (rien que le mot d'humanisme [lui] donnai[t] légèrement envie de vomir) (Houellebecq, 2015a, p. 250).

${ }^{5} \mathrm{We}$ are thinking in particular of his ambition to produce the effect of reality (a term from Roland Barthes) and to show money as the driving force of society.

${ }^{6}$ Houellebecq's creation of character types that are representative of their environment can be read as a nod to Honoré de Balzac, directly evoked in the author's texts (Houellebecq, 2005, p. 151). The quotation from Balzac serves as a motto for Plateforme.

${ }^{7}$ He reads very little or not at all, watches TV series, attends social events with no real desire to do so, etc.

${ }^{8}$ A Balzacian motif par excellence.

${ }^{9}$ ce désastre douloureux et définitif.

${ }^{10}$ This concern for impassivity is emphasized by a detached, cold narration.

${ }^{11}$ tels les homards qui se marchent dessus dans un bocal.
} 
Michel Houellebecq's man - like that of the French novelists of the $19^{\text {th }}$ century - is determined. Biologically - by the instinct for survival and the sexual instinct - and socially by the "milieu and the moment". ${ }^{12}$ Each protagonist is subject to a double pressure with great impact on his moral compass and personal happiness (whatever it means). His daily life is marked by the diktat of ultra-liberal society that intrudes even into the intimate sphere. The first imperative, stemming from economic hypertrophy, is to consume. It is no surprise, therefore, that the writer sees his heroes in consumers and buyers of branded products. ${ }^{13}$ All of them are at the same time consumers of the sexual act in a world where the human body is seen as a marketable product. The second rule is to respect the cult of eternal beauty and youth that inspires the boom of technological means made available to those who deviate from the aesthetic ideal by being old, ugly, sick, not big enough, thin or blond. To emphasize these ideas, Michel Houellebecq quotes the case of Michael Jackson (Houellebecq, 2001, pp. 227-228) and describes meticulously the ugliness of some of his characters. ${ }^{14}$

According to Houellebecq, our ruthless world condemns economically and erotically determined man to success or failure. It is thus logical to ask: does this more and more fetishised push to success mark the initial phase of a process of selection carried out secretly by Western ultra-liberal societies?

\section{Posthumanism - a course towards (un)happiness?}

The negatively laden word selection was used intentionally in the previous sentence. In fact, some critics accuse the writer of reactionary discourse (Lindenberg, 2002). Such an interpretation is clearly wrong and implies a deep misunderstanding, ${ }^{15}$ even though it cannot be denied that Michel Houellebecq's revolt against the doxa offends some sensibilities. It should be noted, however, that similar complaints were voiced against Houellebecq's $19^{\text {th }}$ - and $20^{\text {th }}$ century precursors ${ }^{16}$, and that, through his caustic objections, the author opens the most difficult political, ethical and bioethical issues of our hyper-technologized and hyper-wired society. The contemporary Western world promotes performance and success with no respect for man and his dignity. By creating two distinct categories of characters - the rich, young, good-looking and strong on the one hand, and the left-behind, old, ugly and weak on the other hand Houellebecq seems to unveil the possible implications of the societal diktat on individual freedom and its gradual restriction. "Smoking cigarettes has become the only part of true freedom in my life" (Houellebecq, 1994, p. 61) ${ }^{17}$ admits one of the narrators. Houellebecq's narratives highlight the paradoxes of the libertarian but constraining "human-rights-based" society. His binary vision of humanity, like that of Louis-Ferdinand Céline, ${ }^{18}$ unveils the

\footnotetext{
12 As in Hyppolite Taine's theories.

${ }^{13}$ Michel from Plateforme, for example, wears a trendy rucksack, a Lowe Pro Himalaya Trekking, the most expensive model found in Au Vieux Campeur (Houellebecq, 2001, p. 37).

14 For example Tisserand, a secondary character of the first novel, is described as "fat" (gras) and "stumpy" (courtaud), with "features of a cane toad" (le faciès d'un crapaud-buffle) and "virgin at twenty-eight" (puceau à vingt-huit ans). Due to his physiognomy, he suffers from a lack of erotic attractiveness, as the narrator explains: "Poor, poor boy. I know in my heart why he enjoys my company so much - it's because I never talk about my girlfriends, I never flaunt my success with women. [...] It makes him lose one pain, and it slightly appeases his ordeal." (Pauvre, pauvre garçon. Je sais bien au fond pourquoi il apprécie tellement ma compagnie : c'est parce que moi je ne parle jamais de mes petites copines, je ne fais jamais l'étalage de mes succès féminins, [...] pour lui c'est une souffrance de moins, un léger apaisement de son calvaire) (Houellebecq, 1994, p. 62).

${ }^{15}$ Politically incorrect words are uttered by secondary characters in most cases. In Plateforme for example, the most vehement critic of Islam appears to be a Muslim (Houellebecq, 2001, pp. 338-339).

${ }^{16}$ Gustave Flaubert, Louis-Ferdinand Céline, etc.

${ }^{17}$ Fumer des cigarettes, c'est devenu la seule part de véritable liberté dans mon existence.

${ }^{18}$ Louis-Ferdinand Céline puts it in a straightforward manner: "There are two very different humankinds, the rich one and the poor one." (Il existe deux humanités très différentes, celle des riches et celle des pauvres) (Céline, 1952, p. 85).
} 
stalemate in which liberal democracies got stuck. Old beliefs, ideologies and traditional culture, now considered obsolete, yield to the absence of critical thought and to an ideological vacuum filled by business, high technologies, entertainment and manipulation. Obviously, Michel Houellebecq is not inclined to selection. His Manichean categorization of characters, with members of "the elite" promoted to the rank of protagonists, reflects neither the ideal of Nietzsche's Superman (Übermensch) nor the so-called eugenic ideas. On the contrary, the lack of differentiation ${ }^{19}$ brings forward the common traits of each human, regardless of his/her social status (man or woman, winner or loser, victim or beneficiary of liberalism). Houellebecqian hedonists, looking for ephemeral pleasures and a featureless satisfaction of their desires, are characterized by emotional deprivation, sexual misery, existential emptiness and alienation. Chronically frustrated by the blind and irresistible push to succeed, they engage in a merciless fight on more and more fronts and fields, as the French title of the author's first novel points out (literally: Extension of the Domain of Struggle). This struggle, a "fierce narcissist competition" (Houellebecq, 1991, p. 25; Houellebecq, 2005, p. 22) ${ }^{20}$ which can be read as a caricature of the Will-to-Live (Wille zum Leben) concept coined by Arthur Schopenhauer, ${ }^{21}$ is endless. The pressure of instincts, enhanced by the increasingly insistent diktat of society, can be brought to an end only by the extinction of being. Human struggles are accompanied by perpetual suffering ${ }^{22}$ because every desire, as soon as it is fulfilled, generates boredom, new desires and, consequently, new pains.

Michel Houellebecq's man thus oscillates between a constantly renewed suffering and a "relatively painless" (Houellebecq, 1994, p. 48) ${ }^{23}$ boredom experienced, however, with the same dose of loathing as suffering itself. Happiness is defined only as a temporary cessation of deprivation or pain. Inaccessible to humans, it seems to be reserved for dogs, ${ }^{24}$ as claims one of the narrators. Or should we rather say - reserved for neo-humans derived from genetic manipulation, asexual and immortal, safe from the fear of getting old and dying? The first appearance in Houellebecq's novels of this alternative human species with no sensibility or sensuality dates back to $1998 .{ }^{25}$ In 2005 , the model reappears in an upgraded version. Yet, Houellebecqian neo-humans deprived of the Will-to-Live do not reach happiness. In the final episodes of La Possibilité d'une île, Daniel 25, the last post-biological creature searching for happiness among the ruins of a world without humans, notes that "happiness [is] not a possible horizon" (Houellebecq, 2005, p. 485). ${ }^{26}$ This utterance, placed prominently in the novel, is charged with meaning. The role of two narrators-clones is not to announce a promising future, but to take a relative, suspicious view on transhumanist theories. Both of them bring to light the

\footnotetext{
19 Apart from economic and erotic criteria, considered as the most important success factors, Houellebecq's characters are differentiated according to features that are intrinsic to nature. The author suggests, however, that sex can nowadays be modified and is therefore not a determining factor.

${ }^{20}$ féroce compétition narcissique.

${ }^{21}$ This German philosopher is directly or indirectly evoked in several of Michel Houellebecq's works of fiction (Houellebecq, 2001, p. 175; Houellebecq, 2005, pp. 82, 87, 110, etc.).

22 "The world is an expanded suffering. At its origin, there's a cluster of suffering and every existence is an expansion and a crushing. All things are suffering until they are. Nothingness vibrates with pain, until it reaches the point of being in an abject paroxysm" (Le monde est une souffrance déployée. À son origine, il y a un næud de souffrance. Toute existence est une expansion et un écrasement. Toutes les choses souffrent, jusqu'à ce qu'elles soient. Le néant vibre de douleur, jusqu'à parvenir à l'être : dans un abject paroxysme) (Houellebecq, 1991, p. 9).

${ }^{23}$ relativement indolore.

24 "Fox [= a dog's name] is happy. He scampers round the room [...], he plays with a ball or with his small plastic animals, [...] this is for him an obvious happiness" (Fox, lui, est heureux. Il gambade dans la résidence [...], il joue au balon ou avec un de ses petits animaux en plastique, [...] c'est pour lui un bonheur évident) (Houellebecq, 2005, pp. 77-78).

${ }^{25}$ Publication of Les Particules élémentaires by the Flammarion publishing house.

${ }^{26}$ le bonheur n' [est] pas un horizon possible.
} 
"Balzac-like medium light" (Houellebecq, 2005, p. 151) ${ }^{27}$ perspective of an author who, as says one of the narrators, prefers, "contrary to expectations, a fun approach rather than the one of social denunciation" (Houellebecq, 2001, p. 22). ${ }^{28}$

Michel Houellebecq, a writer with a career in computer science, does not adhere to transhumanist recklessness. He refuses to believe wholeheartedly in the benefits of scientific and technological progress. His comments on the Raëlian sect, full of derision and cynical humour, ${ }^{29}$ are clear evidence of that. Rather, he appears to have affinities with thinkers such as Peter Sloterdijk, who describes today's society as "[post-literary], post-epistolographic, and consequently post-humanist" (Sloterdijk, 2016). Especially in La Possibilité d'une île, recalling a selective cultural encyclopaedia, the French writer rings alarm bells. He warns against ideological rubbish and technological and economic hypertrophy of an ultra-liberal society where the imbalance between "hard" sciences and the ruins of arts and humanities becomes fearfully apparent. The narrator of the first novel puts it coldly: "I do not like this world, [...] I am disgusted by the society I live in, I am sickened by advertising, and computer science makes me throw up. [...] This world needs everything except additional information" (Houellebecq, 1994, pp. 82-83). ${ }^{30}$

\section{Conclusion}

Contemporary man and his ethical concerns - although not always brought to the forefront in the texts - are one of the main focuses of Michel Houellebecq. His works of fiction imagine the imminent end of this "incomplete and transitional being whose destiny [is] to prepare for the advent of a digital future" (Houellebecq, 2005, p. 225). ${ }^{31}$ Deprived of inner life as well as of cultural, ideological and moral dimensions, Houellebecq's man is objectified and flattened. ${ }^{32}$ Yet, his tragic suffering is not subject to criticism. Although perfectly levelled to a set of identical features according to the imperatives of society, the man hic et nunc still keeps the dreams and aspirations of the "old man" of Balzac, Flaubert and other great authors ${ }^{33}$ evoked or pastiched by Michel Houellebecq. Science and technology are advancing at a rapid pace, but can the same be said about human nature? Is not the man of the $21^{\text {st }}$ century as fragile and vulnerable, if not more so, than the man of the great humanist writers?

Michel Houellebecq denounces the impact of our increasingly de-ideologized society's economic and technical hegemony on human morality and happiness. He predicts the possible results of the liberal political system and fears the end of European civilizations that "do not die murdered" but "commit suicide". ${ }^{34}$ Nevertheless, the quest for happiness and a sort of

\footnotetext{
${ }^{27}$ d'un balzacien medium light.

${ }^{28}$ une approche fun plutôt que celle, attendue, de la dénonciation sociale.

${ }^{29}$ The descriptions of the sect, of its commercial practices and its guru are soaked with irony and satire. Several dialogues raise questions about cloning, the role of memory in genetic manipulation, the spiritual side of man, etc. ${ }^{30}$ Je n'aime pas ce monde, [...] la société dans laquelle je vis me dégoûte, la publicité m'écœure, l'informatique me fait vomir. [...] Ce monde a besoin de tout, sauf d'informations supplémentaires. Some other characters subscribe to this idea as well, e.g. Valérie from Plateforme who declares that she does not like this world (Houellebecq, 2001, p. 186).

${ }^{31}$ être incomplet, être de transition dont la destinée [est] de préparer l'avènement d'un futur numérique.

${ }^{32}$ In accordance with the idea of "flat form" evoked in Plateforme.

${ }^{33}$ Houellebecqian characters recall, in one way or another, some older and well-known literary heroes. They are quite close to Meursault and Antoine Roquentin, the solitary and alienated heroes of Albert Camus and Jean-Paul Sartre, or to Jérôme from Georges Perec's Les Choses [Things], to name but a few.

34 "Without Christianity, European nations [are] nothing but soulless bodies, zombies. But could Christianity be revived? I had believed so, I had believed so for a couple of years - with increasing doubts, however, I became more and more marked by Toynbee's thoughts, by his idea that civilizations do not die murdered, but commit suicide" (Sans la chrétienté, les nations européennes n[e sont] plus que des corps sans âme - des zombies. Seulement, voilà : la chrétienté pourrait-elle revivre? Je l'ai cru, je l'ai cru quelques années - avec des doutes croissants, j'étais de plus en plus marqué par la pensée de Toynbee, par son idée que les civilisations ne meurent pas assassinées, mais qu'elles se suicident) (Houellebecq, 2015a, p. 255).
} 
nostalgia for paradise lost are tangentially present in the writings of this bitter humanist who asks real questions without giving quick answers. His works, mixing numerous literary and non-literary genres, convey an urgency to set new benchmarks and reinvent new values before machines transcend the functioning of the human brain. Of course, Houellebecq's narration, contaminated by a crude language, an appropriation of linguistic stereotypes and a falsely scientific style, as well as the shamelessness and the irony of a socio-biological discourse, whose ambiguity might blur the ethical scope, can shock and create controversy. Yet all of this concerns only the visible surface of the texts, covering up a real and legitimate questioning. It is therefore necessary to look beyond the mask that protects this sensitive and lucid novelist who, at a time when our "civilization suffers from vital exhaustion" (Houellebecq, 1994, p. 31 ), ${ }^{35}$ acts as a "sharp observer of contemporary reality" (Houellebecq, 2005, p. 21) ${ }^{36}$ and reveals the great threats hanging over humanity. With full background knowledge.

\section{Acknowledgement}

The article is an outcome of the project VEGA 1/0114/17 Poemata moralia of Gregory of Nazianzus.

\section{References}

BARONI, R. \& ESTIER, S. (2016): Peut-on lire Houellebecq ? Un cas d'illisibilité contemporaine. In: Fabula-LhT, 16 - Crises de lisibilité. [online] [Retrieved March 12, 2019] Available at: http://www.fabula.org/lht/index.php?id=1634

CÉLINE, L.-F. (1952): Voyage au bout de la nuit. Paris: Gallimard.

CLÉMENT, M. L. \& WESEMAEL, S. van (2007): Michel Houellebecq sous la loupe. Amsterdam \& New York: Rodopi.

FOUCAULT, M. (1970): The order of things: An archaeology of the human sciences. New York: Pantheon Books.

FUKUYAMA, F. (1992): The end of history and the last man. New York: Free Press.

HARARI, Y. N. (2016): Homo deus: A brief history of tomorrow. London: Harvill Secker.

HOUELLEBECQ, M. (1991): Rester vivant : méthode. Paris: La Différence.

HOUELLEBECQ, M. (1994): Extension du domaine de la lutte. Paris: Maurice Nadeau.

HOUELLEBECQ, M. (2001): Plateforme. Paris: Flammarion.

HOUELLEBECQ, M. (2005): La Possibilité d'une île. Paris: Fayard.

HOUELLEBECQ, M. (2015a): Soumission. Paris: Flammarion.

LINDENBERG, D. (2002): Le rappel à l'ordre. Enquêtes sur les nouveaux réactionnaires. Paris: Seuil.

MANILÈVE, V. (2015): Michel Houellebecq, le mal-aimé des universitaires français. In: Slate.fr. [online] [Retrieved March 12, 2019] Available at: http://www.slate.fr/story/96947/ universitaires-michel-houellebecq

SLOTERDIJK, P. (2016): Rules for the Human Park. A Reponse to Heidegger's "Letter on 'Humanism'”. In: P. Sloterdijk: Not saved: Essays after Heidegger, trans. I. A. Moore \& Ch. Turner. Cambridge: Polity Press, pp. 193-216. [online] [Retrieved March 12, 2019] Available at: https://www.academia.edu/31233486/Sloterdijk_Rules_for_the_Human_Park

VIARD, B. (2013): Les tiroirs de Michel Houellebecq. Paris: PUF.

\section{Houellebecq's novels in English translation}

HOUELLEBECQ, M. (1998): Whatever, trans. P. Hammond. London: Serpent's Tail.

HOUELLEBECQ, M. (2000): The elementary particles, trans. F. Wynne. New York: Alfred A. Knopf.

\footnotetext{
35 civilisation souffre d'épuisement vital.

${ }^{36}$ observateur acéré de la réalité contemporaine.
} 
HOUELLEBECQ, M. (2002): Platform, trans. F. Wynne. London: William Heinemann.

HOUELLEBECQ, M. (2006): The Possibility of an Island, trans. G. Bowd. New York: Alfred A. Knopf.

HOUELLEBECQ, M. (2012): The map and the territory, trans. G. Bowd. New York: Alfred A. Knopf.

HOUELLEBECQ, M. (2015b): Submission, trans. L. Stein. New York: Farrar, Straus and Giroux.

HOUELLEBECQ, M. (2019): Serotonin, trans. S. Whiteside. New York: Farrar, Straus and Giroux. 